\title{
Implementation and Protection of the Child's Right to Education
}

Suzana Kraljić, Faculty of Law, University of Maribor

\section{Introduction}

he right to education may be dated back to I79I when it was first mentioned in Article I of the then French Constitution. In 1793,

I it was also included in the Declaration of the Rights of Man and of the Citizen (Article 22). According to the Constitution of 1791 and the Declaration of 1793 , the right to education meant the right to public education or schooling, as provided by the state and available free of charge to all citizens (Šimenc and Kodelja, 2015, p. 197). In 1921, the International Labour Organization (ILO) adopted the Coro - Minimum Age (Agriculture) Convention (No. Io), one of the most important milestones in the child's right to education. Article $\mathrm{I}$ of the Convention states: "Children under the age of fourteen years may not be employed or work in any public or private agricultural undertaking, or in any branch thereof, save outside the hours fixed for school attendance. If they are employed outside the hours of school attendance, the employment shall not be such as to prejudice their attendance at school." Still, for millions of children throughout the world, enjoyment of the right to education remains a distant goal. Their age and (im)maturity make children a vulnerable group of the population, one provided with special protection by international and national legal acts. Despite the general vulnerability of children, individual groups of children are particularly vulnerable due to their health (e.g. children with a disability) or the circumstances (e.g. Roma, child soldiers, children facing domestic violence or poverty) in which they find themselves. These children have many of their human and child's rights 
violated, where the right to education is especially vulnerable. Education is critical for the short-, medium- and long-run well-being of any child. This article's chief focus is on implementation and protection of the child's right to education, with four questions under consideration:

a) How is the right of the child implemented in important international human and children's rights treaties?

b) Which protection is given in selected cases of infringements of a child's right to education?

c) How has the ECtHR decided with respect to limitations on the child's right to education?

d) How is the COVID-I9 crisis impacting the child's right to education?

The article builds on the premise that education is the right of every child, not a privilege. Especially these days, the right to education is subjected to various threats. The article analyses some of these and offers solutions (especially those adopted by the ECtHR), which may be used as good practice for Slovenian authorities. Namely, society (national and international) has an obligation to fulfil children's right to education. Another purpose of the article is to provide an overview and insights into children's right to education, which may help teachers, directors, pupils, parents and anyone else interested in the topic improve their knowledge and understanding of this fundamental right of the child. The basic research methodology underpinning the article is doctrinal legal research (also called 'black letter' methodology), which focuses on the letter of the law. Using this method in the present article, the author conducts a descriptive analysis of legal rules relating to the child's right to education (e.g. in international treaties, constitutions, acts, cases). In pursuing the research questions, the article contains introduction and conclusion sections, along with three main chapters: Right to education as the child's right in an international perspective, Right to education in light of the ECHR and its selected judgments and COVID-19 crisis and the child's right to education.

\section{The child's right to education - an international perspective}

Adopted in 1989, the United Nations Convention on the Rights of the Child (UNCRC) is the first international binding instrument to explicitly recognise children as human beings with innate rights (Odink, 2019, p. 2). The UNCRC provides the most complete statement of children's rights ever produced and is the most widely-ratified international human rights treaty in history. The Convention has been ratified by 
196 countries, including all European Union (EU) Member States. ${ }^{1}$ The UNCRC is a landmark treaty on rights of the child, outlining universal standards for all children's care, treatment, survival, development, protection and participation. The Convention covers all aspects of a child's life and sets out the political, civil, social, economic and cultural rights to which all children everywhere are entitled. These rights may be defined as the set of values that adults (e.g. parents, guardians, teachers) should respect in their relationships with children. The principle of best interests (Article 3 UNCRC) should always be the fundamental starting point in all relations and decisions concerning children and their rights (for more, see Kraljić, 2016, 2018, 2019a; Kraljić and Drnovšek, 2019). The UNCRC also explains how adults and governments must work together to ensure that all children can enjoy all of their rights. It is necessary to see the UNCRC as a whole, with all of the rights being linked and holding equal importance (UNICEF, n.d.). It provides children with rights across all areas of their lives, including education.

Today, the right to education is regarded as a common good, one of the most important human rights and a special right of the child. Education is both a human right in itself and an indispensable vehicle for realising other human and child rights (e.g. the right of the child to be heard, to not be discriminated against) (Committee on Economic, Social and Cultural Rights, 1999). Education is an essential creator of any child's life before and after they reach full age.

National education systems vary (e.g. organisation, curricular content). This made it necessary to form key definitions and outlines (e.g. inputs, process, outcomes) so as to enable different national education systems to be compared from a global perspective (UNESCO, 20I2, p. iii). UNESCO's “International Standard Classification of Education ISCED 20II" distinguishes eight levels of education ${ }^{2}$, where primary education is the most protected part of the right to education as a foundation. Primary education is established in various international documents and national constitutions as a minimum educational standard, provided by states to all people, especially children. Secondary and higher education complement primary education but do not enjoy the same protection level as it (Kama,

I See United Nations Treaty Collection - Status of the Convention on the Rights of the Child on I July 2020, retrieved from https://reaties.un.org/Pages/ViewDetails.aspx?s$\mathrm{rc}=I N D \& m t d s g \_n o=I V-$-II\&chapter=4\&clang=_en (2 July 2020). The United States is today the only United Nations member state that is not a party to the UNCRC.

2 The eight ISCED 2 on levels of education: O Pre-primary education; I Primary education; 2 Lower secondary education; 3 Upper secondary education; 4 Post-secondary non-tertiary education; 5 Short-cycle tertiary education; 6 Bachelor or equivalent; 7 Master or equivalent; 8 Doctoral or equivalent. Slovenian 'Basic education' covers level 2 of the ISCED classification. 
2014, p. 150). Therefore, primary education is seen as the "passport to life" (Tawil and Cougoureux, 2013, p. 7). Primary education may be seen as an investment in the child's future and an opportunity for joyful activities, respect, participation, and the fulfilment of ambitions (Committee on the Rights of the Child, 2013, p. 17). It should therefore be free so as to make it possible to include all children in primary education. The need for free and compulsory primary education constitutes the hallmark of international treaties and national constitutions (e.g. Slovenia (Art. 57); ${ }^{3}$ Croatia (Art. 66); Egypt (Art. 19); Latvia (Art. 122); Montenegro (Art. 75 and Art. 79(4)); Norway (Art. I09); Russia (Art. 43); Tajikistan (Art. 4I); Ukraine (Art. 53) etc.) and legal acts on which the right to education is based.

The following international treaties provide the international legal framework of the right to education with the intention of securing free and compulsory education for all children:

a) Article 26 of the Universal Declaration of Human Rights (1948): "Education shall be free, at least in the elementary and fundamental stages. Elementary education shall be compulsory";

b) the UNESCO Convention against Discrimination in Education (1960): "The States Parties to this Convention undertake to formulate, develop and apply a national policy which, ... will tend to promote equality of opportunity and of treatment ... and in particular: (a) To make primary education free and compulsory";

c) Article 13 of the International Covenant on Economic, Social and Cultural Rights (1966): "Primary education shall be compulsory and available free for all";

d) Article 2 of Protocol No. I of the European Convention on Human Rights: "No person shall be denied the right to education";

e) Article II of the African Charter on the Rights and Welfare of the Child (1990): "States Parties to the present Charter shall take all appropriate measures with a view to achieving the full realization of [the right to education] and shall in particular: a) provide free and compulsory basic education";

f) Article 13: I. Everyone has the right to education... 3. The States Parties to this Protocol recognize that in order to achieve the full exercise of the right to education: a. Primary education should be compulsory and accessible to all without cost; b. Secondary education sory and shall be financed from public funds. The state shall create the opportunities for citizens to obtain a proper education". 
in its different forms, including technical and vocational secondary education, should be made generally available and accessible to all by every appropriate means, and in particular, by the progressive introduction of free education; c. Higher education should be made equally accessible to all, on the basis of individual capacity, by every propriate means, and in particular, by the progressive introduction of free education; d. Basic education should be encouraged or intensified as far as possible for those persons who have not received or completed the whole cycle of primary instruction...; and Article 16 of the Additional Protocol to the American Convention on Human Rights in the area of economic, social and cultural rights (Protocol of San Salvador) (1988): “... Every child has the right to free and compulsory education, at least in the elementary phase, and to continue his training at higher levels of the educational system";

g) Article 14 of the Charter of Fundamental Rights of the European Union (20I2): "I. Everyone has the right to education and to have access to vocational and continuing training. 2 . This right includes the possibility to receive free compulsory education...");

h) European Social Charter (1996 revised) - "With a view to ensuring the effective exercise of the right of children and young persons to grow up in an environment which encourages the full development of their personality and of their physical and mental capacities, the Parties undertake, either directly or in co-operation with public and private organizations, to take all appropriate and necessary measures designed: 2. to provide to children and young persons a free primary and secondary education as well as to encourage regular attendance at schools");

i) Article 28 of the UNCRC (1989, p. I): "States Parties recognize the right of the child to education, and with a view to achieving this right progressively and on the basis of equal opportunity, they shall, in particular: (a) Make primary education compulsory and available free to all; (b) Encourage the development of different forms of secondary education, including general and vocational education, make them available and accessible to every child, and take appropriate measures such as the introduction of free education and offering financial assistance in case of need; (c) Make higher education accessible to all on the basis of capacity by every appropriate means; (d) Make educational and vocational information and guidance available and accessible to all children; (e) Take measures to encourage regular attendance at schools and the reduction of drop-out rates... 3. States Parties shall promote and encourage international 
cooperation in matters relating to education, in particular with a view to contributing to the elimination of ignorance and illiteracy throughout the world and facilitating access to scientific and technical knowledge and modern teaching methods. In this regard, particular account shall be taken of the needs of developing countries."4

The state has an important role in ensuring that the right to education is respected, fulfilled and protected. The 'obligation to respect' requires states to avoid measures that hinder or prevent the enjoyment of the right to education, whereas the 'obligation to protect' demands that states take measures which prevent third parties from interfering with enjoyment of the right to education. The 'obligation to fulfil' obliges states to adopt positive measures that enable and assist individuals and communities to enjoy the right to education. The state must act as a guarantor of the right to education (UNESCO, 2015b, p. 75). Unfortunately, practice is quite different to that required by rights law pertaining to humans and children (Klees and Thapliyal, 2007, pp. 502-503). Various studies (Kaur and Singh, 2014; UNDP Bangladesh, n.d.; Zhang, Li, and Xue, 2015) have found significant differences in education between rural and urban areas. According to the Food and Agriculture Organisation of the United Nations (FAO), in 2015 about 57 million primary-school-age children did not attend school. Over four out of five of these children live in rural areas $(\mathrm{FAO}, 2020)$. This difference in knowledge and education levels between rural and urban areas is called the "urban-rural education divide". It is the main barrier to achieving universal primary education and also seen as a key obstacle to the eradication of poverty and hunger, the promotion of gender equality, and empowerment of women (FAO, n.d.).

People's mobility, whether voluntary (e.g. marriage, work) or forced (e.g. war refugees, disaster-induced displacement), also affects the growth of cultural diversity and children's right to education. Especially occurrences related to violence (e.g. terrorism, drug-related violence, wars,

4 Also, Article 3 of the Slovenian Zakon o osnovni soli (Basic School Act) states that basic education in Slovenia is compulsory. The boundary between ISCED level o (pre-primary education) and level I (primary education) coincides with the transition point in the education system where systematic teaching and learning in reading, writing, and mathematics begins. The only entry requirement at this level - primary education - is the age of the child (UNESCO Institute for Statistics, 2012, pp. 29-30). The legal age of entry to basic education in Slovenia is 6 years. Since basic education in Slovenia is compulsory, parents are obliged under Article 45 of the Basic School Act to enrol children in the first grade of basic school who will reach the age of 6 in the calendar year in which they start attending school. Parents are allowed to choose between public schools, private schools and home-schooling. On the parents' suggestion, a suggestion of the healthcare service, or based on a decision on guidance, the child may be postponed by r year if it is established that the child is not ready to start school. 
internal conflicts, even intra-family violence) influence children's right to education. Such conflicts, wars and crises mean that almost 30 million children are deprived of their right to a primary education, creating generations of uneducated future adults (UNESCO, 2015b, p. 16). The proportion of out-of-school children in countries affected by conflicts rose from 30 percent in 1999 to 36 percent in 2012 (United Nations, n.d.). Namely, especially in a time of armed conflicts and conflict-affected areas, the right to education is often particularly impaired and its quality suffers. Usually, problems arise from a lack of basic capacities for ensuring education (e.g. the lack of proper buildings, teaching staff, books). The two biggest constraints on access to education in such circumstances are insecurity and poverty (e.g. the lack of decent clothes, the involvement of children in contribution to the household's livelihood through paid/unpaid work, taking care of younger siblings or sick relatives, the problem of transport to school) (Sinclair, 2007, p. 53). It is necessary and urgent to ensure the early inclusion of children who have already been deprived of the right to education due to such circumstances (e.g. armed conflicts), and to eliminate or limit even greater consequences as soon and as far as possible. The states shall try to make the education available, accessible, acceptable and adaptable.

\section{Right to education in light of the ECHR and its selected judgments}

As parties of international and regional legal instruments, states are obliged to protect the child's right to education. Their failure to protect the right to education constitutes an infringement of this right and also violates international law. Although the right to education is one of the child's fundamental rights, states repeatedly breach it. Violations of the right to education may occur through the direct action of states (acts of commission) or because states did not adopt the measures needed to exercise this child right (acts of omission) (Committee on Economic, Social and Cultural Rights, 1999, p. 15). Consequently, those violations are also subject to judicial review. Since states are to protect, respect and fulfil the child's right to education, the European Court of Human Rights (ECtHR) has an important role to play. While its judgments are only binding on the Parties, many ECtHR judgments also have impacts extending beyond the confines of the particular case.

The right to education is included in Article 2 of Protocol I of the ECHR, which provides for two separate rights: the general individual right to education and the right of parents to education in conformity with their religious and philosophical convictions (Council of Europe, 2019, p. 5). The general individual right to education is declared using 
negative wording ("No person shall be denied the right to education"). The holders of the right to education guaranteed in Article 2 of Protocol I are children as well as any person regardless of age who wishes to benefit from the right to education. States should ensure that everyone has access to education, yet national regulations related to primary education vary. For example, differences may emerge in the age until education is compulsory or whether home-schooling is (dis)allowed. The second sentence of Article 2 builds on a state's positive obligation to respect the religious and philosophical convictions of the parents: "In the exercise of any functions which it assumes in relation to education and to teaching, the State shall respect the right of parents to ensure such education and teaching in conformity with their own religious and philosophical convictions"; here, the word "convictions" should not be equated with "opinion" or "idea" as that indicates a certain level of cogency, seriousness, cohesion and importance.

Based on the above, states should take religious and philosophical pluralism into account while planning the educational curriculum. The conveyance of religious and philosophical content must be objective, critical and plural in manner (Grabenwarter, 2014, p. 398; Novak, 2004, p. 191; also see Case Folgero and Others v. Norway). Only in this case will no violation of parental care or of parents' convictions be recognised. In the case Dojan v. Germany, the parents requested that their children to be exempted from sex education as they belonged to the Christian Evangelical Baptist Church and held strong moral beliefs as part of their religious faith. The ECtHR observed the sex-education classes at issue aimed at the neutral transmission of knowledge regarding procreation, contraception, pregnancy and childbirth following underlying legal provisions and the ensuing guidelines and the curriculum, all based on current scientific and educational standards. In the case $A R$ and $L R v$. Switzerland, the ECtHR again dealt with the issue of sex education. The ECtHR stressed that one aim of sex education is to prevent sexual violence and exploitation, which pose a genuine threat to the physical and mental health of children and against which children of all ages must be protected. Therefore, sex education did not affect the right to parental education unless it pursued an aim of indoctrination which could be viewed as not respecting the religious and philosophical convictions of the parents ( $A R$ and LR v. Switzerland). Consequently, sex education is declared as needed to ensure the child's best interest and also included in the state school curriculums in Slovenia. But it must pursue legitimate aims (e.g. to protect children from sexual violence and offences) and be objective, pluralistic and critical. 
In the Belgian Linguistic case, the applicants and their children (in total, over 800 persons) asserted that the law of the Dutch-speaking regions in which they lived did not include adequate provisions for Frenchlanguage education. They also argued that the state did not allow the applicants' children to attend French classes in certain places, forcing the applicants to enrol their children in local schools or send them further afield, entailing risks and hardships. The ECtHR opined that the right to education implied the right to be educated in the national language, and did not include the provision that the parents' linguistic preferences be respected (Belgian Linguistic case). Further, in Appel-Irrgang and Others v. Germany, the ECtHR highlighted that the inclusion of compulsory secular ethics ${ }^{5}$ classes without any possibility of exemption fell within the margin of appreciation afforded to states under Article 2 of Protocol No. I.

The right to education is not absolute and may be subject to implicit limitations (Council of Europe, 2019, p. 5). Interferences must meet the principle of proportionality requirements and never violate the substance of the right to education (Grabenwarter, 2014, p. 392). The states enjoy a certain margin of appreciation in assessing whether and to what extent differences in otherwise similar situations justify different treatment. In the ECtHR's opinion, a state's margin of appreciation in this domain increases with education level, in inverse proportion to the importance of that education for those concerned and for society at large. Thus, at the university level, which remains optional for many people, higher fees for foreign students seem commonplace and might be considered fully justified in the present circumstances. Yet, the opposite goes for primary education, which provides basic literacy and numeracy as well as integration into and first experiences of society and is compulsory in most countries. Secondary education (relevant to the present case) falls between these two extremes. The difference is seen in the ordering of sub-paragraphs (a), (b) and (c) of Article 28(I) UNCRC, where the first paragraph prescribes that states shall make primary education compulsory and available free to all. The second and third paragraphs merely call on the states to encourage the development of different forms of secondary education and appropriate measures like the introduction of free education and offering financial assistance in case of need and to make higher education accessible to all based on capacity by all appropriate means. The ECtHR wrote that secondary education plays an ever-increasing role in successful personal development and individuals' social and professional integration. In modern 
society, having no more than basic knowledge and skills constitutes a barrier to successful personal and professional development (Ponomaryovi $v$. Bulgaria ${ }^{6}$, paras. 56-7). Any restriction of the right to education must be predictable for those it applies to and follow a legitimate aim. A limitation is only compatible with Article 2 of Protocol No. I if there is a reasonable relationship of proportionality between the means employed and the aim sought to be achieved.

The ECtHR did not find any legitimate aim in the case Catan and Others $v$, the Republic of Moldova and Russia. Transdniestria is a region in Moldova that declared independence in 1991, but this has not been recognised by the international community. In 1992, the crisis of Romanianlanguage schools began when the Transdniestrian "Supreme Council" adopted a 'law on languages' stipulating that Moldovan (another term for the Romanian language spoken in Moldova) must be written in Cyrillic instead of the Latin alphabet. To enforce this policy, the Transdnistrian authorities forbade the use of Latin script in schools across Transdniestria. However, eight Romanian-language schools, including the "Ștefan cel Mare și Sfânt" lyceum, continued to use Latin script, at times clandestinely. Consequently, the schools suffered from a vigorous campaign of intimidation by authorities, included being evicted from some school buildings, vandalism of others, interrupted water and electricity supplies, and cumbersome border checks for goods as well as teachers and pupils in some cases. A school from Grigoriopol was also evicted from its premises by Transdniestris 'police' and forced to relocate $20 \mathrm{~km}$ away, in Moldovancontrolled territory (Hamid, 2020). In this case, the ECtHR stressed the fundamental importance of primary (and secondary) education for every child's personal development and future success. This made it impermissible to interrupt the children's education and force them and their parents to make difficult choices for the sole purpose of entrenching the separatist ideology.

6 In this case, the applicants were Russian nationals who did not hold Bulgarian permanent residence permits during the relevant period; nor did they otherwise fall into any category that would have enabled them to avoid having to pay the fee charged (EUR 800 and EUR 2,600 ) to certain aliens undertaking their secondary education in Bulgaria under Bulgarian law. Both received permanent residence permits, but the Bulgarian court held that this only prevented them from having to pay school fees in the future, not for fees charged before residence was granted. They alleging they had been discriminated against in breach of Article 14 of the ECHR and Article 2 of Protocol I because, unlike Bulgarian nationals and certain other categories of alien, they had been required to pay fees in order to pursue their secondary education. They also highlighted that they were children during the relevant period and that, under Article 28 of the CRC, the state had a duty to assist children become fully fledged members of society. 
The ECtHR has in many cases addressed the difficulties relating to the education of Roma children. Namely, Roma people's educational level is below the general educational level of other segments of the population (Kraljić, 2019b). The Roma are today a specific disadvantaged and vulnerable minority, with their vulnerability meaning that a difference in treatment to correct the lack of equality may be required in particular circumstances. In the case Sampanis and Others v. Greece (para. 85), the ECtHR stressed the competent authorities should facilitate Roma children's enrolment in school, even if certain required administrative documents were missing. Activities of this nature could contribute to high literacy rates of Roma children, reduce the drop-out school rate, lower the share of students who complete just primary education, and increase the school attendance of Roma children (Kraljić, 2019b). On the other hand, homogeneous departments containing only Roma children have been described by the ECtHR (D. H. and Others v. Czech Republic, Sampanis and Others v. Greece, Oršus and Others v. Croatia) as segrementary and discriminatory. Arranging the education curriculum for Roma children must ensure safeguards for their special needs. The decision must be transparent and based on clearly defined criteria, not simply ethnic origin. Such measures cannot be considered reasonable and proportionate if they would lead to an education that brings the problems of Roma children together and jeopardises their further personal development, instead of tackling their real problems or helping them integrate into ordinary schools and develop skills that would facilitate life among the majority population (D.H. and Others v. the Czech Republic, para. 207).

Following the analysed decisions of ECtHR, there is no doubt that the child's right to education is recognised and respected as a fundamental right and holds immense importance for children in their childhood and adulthood. The right to education can be subjected to limitations, but they must be objective, proportional and not violate other children's rights. States must ensure, through their authorities, that the laws and measures deriving from them respect and enable realisation of the child's right to education.

\section{The COVID-19 crisis and the child's right to education}

Classroom-centred learning is nowadays challenged by the expansion of access to knowledge and the emergence of learning spaces beyond the traditional classroom (UNESCO, 2015b, p. 49). We are living in a time of the fourth industrial revolution, a new era that builds and expands the impact of digitalisation in novel and unanticipated dimensions. Its technologies are already changing all areas of our day-to-day lives as well as 
education. This was very evident during the time of the COVID-I9 pandemic that saw the teaching process move overnight in Slovenia and other states from 'the bench to behind screens'. Most countries have, at least partly if not entirely, closed their schools. As at 27 July 2020 , schools in I07 countries had shut their doors (country-wide closures). This affected $1,066,817,855$ learners or 60.9 percent of all enrolled learners. Still, the peak was reached on 2 April 2020 when country-wide closures were seen in 194 countries, impacting $1,598,099,008$ learners or 91.3 percent of all enrolled learners (UNESCO, 2020a). These new circumstances before us for only a few months have, according to initial estimates, already led to an "educational crisis" (Human Rights Council, 2020, p. I).

In principle, the move itself to education to online distance learning was not a problem for many children given they are very familiar with digitalisation. Yet, it should not be overlooked that the social and economic differences between children have become even more noticeable. Many children did not have a suitable computer, printer or Internet connection to allow them to be included equally in this new way of teaching. It should also not be forgotten that many did not have a private and quiet corner to permit them to integrate seamlessly into the pedagogical process and learning.

As one of the most vulnerable groups, children are currently (in the 'COVID-I9 crisis') further exposed to encroachments on their rights. Interventions may relate to restrictions or even violations. Although the circumstances arguably dictate justified restrictions on children's rights, special care must be taken to avoid violations and the resulting short- or even long-term consequences. A fundamental right of children currently in the spotlight is undoubtedly the right to education. Even though the implementation and continuation of distance learning were quickly organised and arranged, it should not be overlooked that this method is particularly susceptible to exacerbating the differences already present in the 'regular teaching process'. Namely, distance online teaching depends on modern technology (e.g. computer, telephone, a good Internet connection), which unfortunately could not be provided to all children. Half the total number of learners (around 826 million students) kept out of the classroom by the COVID-19 pandemic do not have access to a household computer and 43 percent (706 million) have no Internet at home (UNESCO, p. 2020b). This certainly infringes on children's right to have access to adequate education.

We should also not ignore the fact that, even if all of the above is provided, more problems arise when the family has a larger number of 
children, especially the question of whether equal access can be ensured for all children in the family. The family's housing capacity might also influence the quality of the right to education. While it is often impossible to assure a child a private corner in ordinary circumstances, in a time of COVID-19 it is even more difficult to find a place in the home to carry out online education (e.g. listening to lectures).

The right to education has also been enormously curtailed for children in need of learning support (e.g. children with special needs, children of migrants, Roma, children in hospitals). Even talented pupils may have been deprived of the challenges they receive at school. Of course, children exposed to domestic violence at home should not be ignored since school has often been a safe place for them to escape their home environment, at least for a while. Now, at a time of the COVID-ig crisis, the restriction of movement means this escape is not possible at all. The fact that, already in 'normal times', many children face poverty makes the food available at school often crucial for them, perhaps even their only quality daily meal. We are moreover currently in the cold period of the year (winter) and some families cannot provide adequate heating for their homes (Lancker and Parolin, 2020) and also from this point of view such children are at a disadvantage. We may conclude with certainty that the COVID-I9 crisis has significantly affected children's lives and thereby their rights, especially the right to education, which is also linked to other rights (e.g. right to privacy, right to play).

Teaching and learning have become more informal, mobile and impersonal with the transition to 'behind the screen'. How deeply this has exacerbated the already existing inequality (e.g. between poor and rich, rural and urban, boys and girls) and how children's right to education has suffered may never be fully known as much remains hidden behind closed family doors. Still, we can be sure that the consequences will bring considerable short- and probably long-term impacts on both the Slovenian and especially global levels, especially for the most vulnerable children (e.g. drop-out is on the rise (Dwawan, 2020)). Therefore, it is crucial that online distance learning is only seen as a temporary solution for addressing the COVID-19 crisis. The digitalisation of education should never replace on-site schooling with teachers (Human Rights Council, 2020, p. 2). 'Traditional' on-site learning can better focus on the needs of an individual child or a vulnerable group of children. The direct contact between teacher and pupil makes it easier to identify the child's needs and the possibilities for providing them. This then also ensures a better exercise of the right to education and other children's rights. 


\section{Conclusions}

Even though the right to education is declared in various international treaties, also as a fundamental right of the child, it is still not available to all children. Article 28 of the UNCRC emphasises that every child should enjoy the right to education. States should make primary education compulsory and available free to all. Yet, despite living in the 2 ist century, many children today still experience limits on their access to education. The right to education, as a fundamental child right, is also subjected to infringements. The obstacles to education are based on different circumstances caused by humans (e.g. war, discrimination) or nature (e.g. natural disasters, epidemics). Such special situations, including the COVID-I9 pandemic, might lead to a whole generation of children being traumatised, un(der)-educated and unprepared to contribute to the social and economic recovery of their country or region (UNESCO, 2015a, p. 34). Swift actions are needed by all international and national stakeholders to ensure that children and their rights are adequately protected as soon as possible. The ECtHR has an essential role to play in ensuring the implementation and protection of the child's right to education, especially as concerns limitations of this right, where the implementation, protection and limitation must be objective and proportional. Untimely and inappropriate actions, perhaps even complete passivity, might also cause irreparable and serious consequences for children. We still have a long way to go before the international community and individual states come as close as possible to what is the best and most feasible to do in a given situation or moment to ensure and protect children and their right to education.

\section{References}

Committee on Economic, Social and Cultural Rights (1999) General comment No. 13: The right to education (article 13). Retrieved from: https:// www.ohchr.org/EN/Issues/Education/Training/Compilation/Pages/d) GeneralCommentNor3 Therighttoeducation(articler3)(1999).aspx (2 July 2020).

Committee on the Rights of the Children (2013) General comment No. I4 (2013) on the right of the child to have his or her best interests taken as a primary consideration (art. 3, para. I). Retrieved from: https://www2. ohchr.org/English/bodies/crc/docs/GC/CRC_C_GC_I4_ENG.pdf (27 July 2020).

Council of Europe (2019) Guide on Article 2 of Protocol No. I to the European Convention on Human Rights - Right to Education. Updated on $3 I$ August 2019. Strasbourg: Council of Europe. 
Dwawan, S. (2020) Online Learning: A Panacea in the Time of COVID-r9 Crisis. Journal of Educational Technology Systems 49(I), pp. 5-22.

FAO (Food and Agriculture Organization of the United Nations) (2020) Sustainable Development Goals - Millennium Development Goal 2: Achieve universal primary education. Retrieved from: http://www.fao. org/sustainable-development-goals/mdg/goal-2/en/ (I2 July 2020).

FAO (Food and Agriculture Organization of the United Nations) (n.d.) FAO and the eight-millennium development goals. Retrieved from: http://www.fao.org/3/a-az95oe.pdf (23 June 2020).

Grabenwarter, C. (2014) European Convention on Human Rights Commentary. München: C. H. Beck - Nomos - Helbing Lichtenhalm Verlag.

Hamid, L. (2020) The right to education in Transdniestria seven years after Catan and Others v. Moldova and Russia: Are we there yet? Strasbourg Observers, 20 April 2020. Retrieved from: https://strasbourgobservers. $\mathrm{com} / 2020 / 04 / 20 /$ the-right-to-education-in-transdniestria-seven-yearsafter-catan-and-others-v-moldova-and-russia-are-we-there-yet/ (13 July 2020).

Human Rights Council (2020) Right to education: impact of the COVID-r9 crisis on the right to education; concerns, challenges and opportunities. A/HRC/44/39.

Kama, S. (2014) Another Dimension of the Right to Education: is "Equally Accessible Higher Education” a Dream? Queen Mary Human Rights Law Review I(I), pp. I 49-173.

Kaur, A., and Singh, K. (2014) Role of Teacher Education in the Achievement of MDGs. International Journal of Evaluation and Research in Education 3(2), pp. 125-132.

Klees, SJ., and Thapliyal, N. (2007) The Right to Education: The Work of Katarina Tomasevski. Comparative Education Review 5I(4), pp. 497-510.

Kraljić, S. (2016) I2. člen KOP - pravica otroka do svobodnega izražanja v sodnih in upravnih postopkih. Pravosodni bilten 37(I), pp. II-30.

Kraljić, S. (20I8) Berücksichtigung der Meinung des Kindes: ein Einblick in das neue Familiengesetzbuch und in die aktuelle slowenische Rechtsprechung. In Ünver, Y., and Kraljić, S. (eds.). Çocuk haklari $=$ Kinderrechte in der Rechtsvergleichung $=$ Children's rights in comparative law. VI. Turkish-Slovenia Comparative Law Symposium, Özyeğin University Faculty of Law, Ljubljana University Faculty of Law, Maribor University Faculty of Law, I. October 2017, pp. 13-40. Ankara: Seçkin, Hukuk. 
Kraljić, S. (2019a) Die Reflexion des Kindesinteresse in der neuen slowenischen Rechtsprechung. In Kraljić, S., and Ünver, Y. (eds.). Compendium of contemporary legal issues, pp. I-I5. Maribor: Univerzitetna založba Univerze: Faculty of Law.

Kraljić, S. (2019b) The position of Roma community in Slovenia in the light of legal regulation and current situation (education, employment, health, housing). In Kraljić, S., and Klojčnik, J. (eds.). From an individual to the European integration: discussion on the future of Europe: liber amicorum in honour of prof. emer. dr. Silvo Devetak on the occasion of his 8oth birthday, pp. 331-347. Ist ed. Maribor: University of Maribor Press.

Kraljić, S., and Drnovšek, K. (2019) Pomen in vloga pravnega standarda največje otrokove koristi v novem slovenskem Družinskem zakoniku in sodobni sodni praksi. In Šago, D. (ed.). et al. Aktualnosti gradanskog procesnog prava - nacionalna i usporedna pravnoteorijska i praktična dostignuća: zbornik radovas $V$. medunarodnog savjetovanja, pp. II3I29. Split: Pravni fakultet.

Lancker, Van V., and Parolin, Z. (2020) COVID-19, school closures, and child poverty: a social crisis in the making. The Lancet 5(5), e243-e244.

Novak, B. (2004) Šola in otrokove pravice. Ljubljana: Pravna Fakulteta in Cankarjeva založba.

Odink, I. (2019) Children's rights in the EU - Marking 3 o years of the UN Convention on the Rights of the Child. European Union - European Parliamentary Research Service. Retrieved from: https://www.europarl.europa.eu/RegData/etudes/BRIE/2019/644175/EPRS_ BRI(2019)644175_EN.pdf (2 July 2020).

Sinclair, M. (2007) Education in emergencies. Commonwealth Education Partnerships 2007. Retrieved from: https://www.researchgate.net/publication/44827068_Education_in_emergencies (30 July 2020).

Šimenc, M., and Kodelja, Z. (2015) Vsebina človekove pravice do izobraževanja. Šolsko polje 26(3-4), pp. 195-215.

Tawil, S., and Cougoureux, M. (2013) Revisiting Learning: The Treasure Within Assessing the influence of the 1996 Delors Report. Paris: UNESCO.

UNDP Bangladesh (n.d.) A Situation Analysis Report on Education (MDG 2) - Bangladesh - A Baseline for Needs Assessment and Costing. Retrieved from: https://planipolis.iiep.unesco.org/sites/planipolis/files/ ressources/bangladesh_mdg_situation_analysis.pdf(23 July 2020).

UNESCO (2015a) Education 2030 - Incheon Declaration Towards inclusive and equitable quality education and lifelong learning for all. 
Retrieved from: https://unesdoc.unesco.org/ark:/48223/pfooo0245656/ PDF/245656eng.pdf.multi (27 July 2020).

UNESCO (2015b) Rethinking Education - Towards a global common good? UNESCO: France.

UNESCO (2018) Global Education Monitoring Report 2019 - Migration, displacement and education: Building bridges, not walls. Paris: UNESCO Publishing.

UNESCO (2020a) COVID-Ig Impact on Education. Retrieved from: https:// en.unesco.org/covidı9/educationresponse (27 July 2020).

UNESCO (2020b) Startling digital divides in distance learning emerge. Retrieved from: https://en.unesco.org/news/startling-digital-divides-distance-learning-emerge (27 July 2020).

UNESCO Institute for Statistics (2012) International Standard Classification of Education - ISCED 20II. Montreal: UNESCO-UIS 20I2. http://uis.unesco.org/sites/default/files/documents/international-standard-classification-of-education-isced-20ri-en.pdf (23 July 2020).

UNICEF (2007) A Human Rights-Based Approach to 'Education for all'. A framework for the realization of children's right to education and rights within education. New York: UNICEF.

UNICEF (n.d.) What is the UNCRC? Retrieved from: https://www.unicef. org.uk/what-we-do/un-convention-child-rights/ (28 July 2020).

United Nations (n.d.) Millennium Developments Goals and Beyond 2015 Goal 2: achieve universal primary education. Retrieved from: https:// www.un.org/millenniumgoals/education.shtml (30 July 2020).

United Nations Treaty Collection - Status of the Convention on the Rights of the Child on the I July 2020 . Retrieved from: https://treaties.un.org/ Pages $/$ ViewDetails.aspx?src $=I N D \& m t d s g \_n o=I V-$ II \&chapter $=4 \&-$ clang=_en (2 July 2020).

Zhang, D., Li, X., and Xue, J. (2015) Education Inequality between Rural and Urban Areas of the People's Republic of China, Migrants' Children Education, and Some Implications. Asian Development Review $32(I)$, pp. 196-224.

\section{Sources}

African Charter on the rights and welfare of the child. Retrieved from: https://www.un.org/en/africa/osaa/pdf/au/afr_charter_rights_welfare_ child_africa_1990.pdf(I2 July 2020).

American Convention on Human Rights in the area of economic, social and cultural rights (Protocol of San Salvador 1988). Retrieved from: https:// www.oas.org/dil/1988\%20Additional\%20Protocol\%20to\%2othe\%20 
American\%20Convention\%20on\%2oHuman\%2oRights\%2oin\%20

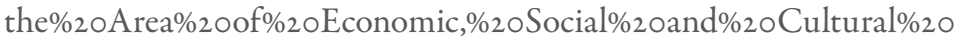
Rights\%20(Protocol\%20of\%20San\%20Salvador).pdf (20 July 2020).

Charter of Fundamental Rights of the European Union (CFREU): Uradni list Evropske unije, C 83/389.

Convention against Discrimination in Education (CADE): Uradni list RS, št. $9 / 92$.

Convention for the Protection of Human Rights and Fundamental

Freedoms (ECHR): Uradni list RS, št. 33/94.

European Social Charter (revised): Uradni list RS - MP, št. 7/99.

International Covenant on Economic, Social and Cultural Rights (ICESCR):

Uradni list RS - MP, št. 9/92.

United Nations Convention on the Rights of the Child (UNCRC): Uradni list RS - MP št. 9/92.

Universal Declaration of Human Rights (UDHR): Uradni list RS, št. 24/ı8.

Zakon o osnovni šoli (ZOsn - Basic School Act): Uradni list RS, št. 8I/o6 - official consolidated text, I02/07, I07/10, 87/II, 40/12 - ZUJF, 63/13, 46/16 - ZOFVI-L.

\section{Case law}

Appel-Irrgang and Others v. Germany, app. no. 45216/07, 6 October 2009. A.R. and L.R. v. Switzerland, app. no. 22338/15, 19 December 2017.

Case 'relating to certain aspects of the laws on the use of languages in education in Belgium (so-called the Belgian linguistic case), app. nos. 1474/62; 1677/62; 1691/62; 1769/63; 1994/63; 2126/64, 23 July 1968.

Case Oršuš and Others v. Croatia, app. no. 15766/03, 16 March 2010.

Catan and Others $v$. the Republic of Moldova and Russia, app. nos. 43370/o4; 8252/05; 18454/06, I9 October 2012.

D. H. and Others v. Czech Republic, app. no. 57325/00, 13 November 2007.

Dojan v. Germany, app. no. 319/08, 13 September 2011.

Folgero and Others $v$. Norway, app. no. 15472/02, 29 June 2007.

Ponomaryovi v. Bulgaria, app. no. 5335/05, 28 November 201 I.

Sampanis and Others v. Greece, app. no. 32526/05, 5 June 2008. 